\title{
Managing budgetary openness of public services
}

\author{
Elena Razinova* \\ ${ }^{1}$ Perm National Research Polytechnic University, Komsomolsky prospekt, 29, Perm, 614990, Russia
}

\begin{abstract}
The analysis of the aspects of information transparency of public finance in terms of public services (lists of public services, government assignments and information on subsidies for financial support of government assignments, cost standards for the provision of public services) at the federal and regional levels. Regulatory legal acts of the constituent entities of the Russian Federation, official websites of executive authorities and specialized federal resources for publishing budget data are considered. In accordance with the identified contradictions, the information objects published at the federal and regional levels were ranked according to the level of budgetary openness, and areas of improvement associated with increasing the level of accessibility and transparency of public finance data were identified.
\end{abstract}

\section{Introduction}

According to the recently published materials of the Federal Service for Supervision of Communications, Information Technology and Mass Media of the Russian Federation, the restriction of the right to receive information is at the top of the pyramid of digital threats [1]. Representatives of the expert community call big data "new gold" [2] and "new oil", which actualizes the value of information accessibility in the modern world, and increasing openness and transparency is one of the global trends and prospects for the development of the public sphere.

Proactive mode of public access to official, statistical, budgetary and other information administered by public authorities that meets the criteria of relevance and cognitive accessibility, interaction between the state and public institutions, citizen participation in decision-making ensure the implementation of the concept of openness of the state [3].

At present, special importance is attached to budgetary openness, the high level of which scientists associate with positive economic effects: a decrease in the level of corruption, an increase in the level of public trust and an intensification of an open dialogue [4]. Despite the obvious successes of the Russian Federation in this area (in the Open Budget survey of the International Budget Partnership for 2019 [5], Russia took 14th place out of 117 countries, moving up two positions compared to the previous version of the ranking), researchers highlight contradictions and areas of improvement. It is associated with an increase in the degree of detail of information on budgetary indicators, including about state and municipal institutions, including information about the services they provide, parameters of compliance with requirements for the quality of services and the principles and conditions of their financial support [6].

\section{Methods}

At the moment, the general concept of "openness" in the aspect of the analysis of public institutions is debatable, in the scientific and practical environment there is no uniform approach to its definition, while the concepts of an applied and instrumental nature are most often used. So, according to experts of the Accounts Chamber of the Russian Federation, the directions of the state's openness are open dialogue (the availability of mechanisms for public participation), open data (the availability of tools for proactively obtaining the necessary and relevant information, technical and functional accessibility) and the openness of information - the availability of regulatory and communication tools, allowing citizens and organizations to receive data supervised by state and local authorities and budgetary organizations [7].

Openness of the budget as a direction of research has a broader theoretical and practical basis. So, in terms of research on foreign experience that determines the vector of development of Russian budgetary openness, the works of N.A. Guz [8], N.V. Golovanova [9] and others. Analysis of domestic practice, identification of problems and areas of improvement is carried out in the studies by A.M. Lavrova, O. I. Timofeeva, V.V. Klimanov and A.A. Mikhailova [6] and others.

The principle of transparency (openness) of the budget since 2007 is enshrined in Art. 36 of the Budget Code of the Russian Federation and presupposes the obligatory publication in the media of approved budgets and reports on their implementation, completeness of information on the progress of budget execution, as well as the availability of other 
information on budgets by decision of legislative (representative) government bodies; mandatory openness to society and the media of draft budgets, procedures for considering and making decisions on draft budgets; providing access to information posted on the information and telecommunications network "Internet" on a single portal of the budgetary system of the Russian Federation; stability and (or) continuity of the budget classification of the Russian Federation, budget indicators. These indicators, as a rule, are analyzed and evaluated in the framework of world ratings and reviews.

Speaking broadly about budgetary transparency, we should mention the relevance of publishing the expanded and detailed set of data on public finance, in particular, on financing state and municipal institutions, including quantity, scope, cost of services provided (works performed), and specifying the applicable standards in official documents [4]. Thus, we speak about information transparency within the context of different structural elements of public finance, which we identify as budgetary transparency within our study. We should mention that we could rate highly such information in terms of social significance as it is aimed at understanding social processes, including the process of financing social organization directly connected to the provision of decent standard of living for citizens.

Researchers distinguish the following approaches to the exercise of the right for access to information provided by government authorities or organizations: the active approach (individual search of information in various sources) and the proactive approach when citizens consume information whether they have or do not have the purpose to do so (through mass media, social media, etc.) [10]. From our point of view, now there is the third approach which combines the features of the above-mentioned approaches: information is published in the public domain (on special resources or websites of executive authorities) in a maximum available form, which makes it convenient to process and analyze it. As an example demonstrating the synthesis of the described approaches, we can consider the Budget for Citizens project-a document that provides publishing the budget and budget implementation reports in a maximum available form. This document is drawn up to familiarize users interested with the tasks and priority areas of the budgetary policy, major conditions of budget formation and implementation, major budget parameters; since 2013, it shall be published annually at all levels of governmental units: federal, regional, and municipal. At the same time, the structure of data published within the project generally complies with the requirements of international ratings (in particular, the International Budget Partnership rating) and excludes the information on the finance of public organizations.

We should note that within the study the analysis object includes documents (regulations) and public information on government services in terms of the active approach (documents, presentations, open data, interactive websites) in the context of activities of governmentally, municipally and privately owned institutions which provide satisfaction of material and spiritual needs of citizens. We used the methods of content and document analysis: to determine the level of budgetary transparency of government services, we analyzed the regulations of the supreme executive bodies of the constituent entities of the Russian Federation, including the procedure for preparing the government assignment for government services (works) and the financial security of the government assignment issued in accordance with Article 69.2 of the Budgetary Code of the Russian Federation, and public information published on the Single Portal for the Budget System of the Russian Federation (http://budget.gov.ru), the Official website for information on government and municipal institutions (https://bus.gov.ru, the website of GMU), official websites of executive authorities of the federal and regional levels.

\section{Results and discussion}

In accordance with Article 69.2 of the Budget Code of the Russian Federation, the composition of public services and works included in the state assignment the basis for financial support of state organizations, is accumulated within the framework of the all-Russian basic (sectoral) lists (classifiers) of state and municipal services provided to individuals (can be used by institutions of all levels publicly - legal entities), federal and regional lists (classifiers) of public services that are not included in the all-Russian basic (sectoral) lists (classifiers) of state and municipal services provided to individuals, and works, the provision and implementation of which is stipulated by the regulatory legal acts of the Russian Federation ( subjects of the Russian Federation). Up-to-date information on allRussian, federal and regional lists is published on the Single Portal for the Budget System of the Russian Federation, including in the open data format.

Government assignments for government services (at the federal and regional levels) are placed both on the Single Portal for the Budget System of the Russian Federation and the website of government and municipal institutions. This information object has a relatively high level of transparency, where information is published both as an original document and as data adapted for an unlimited set of people. According to the website of government and municipal institutions, in 2021 there have been published $93.41 \%$ of government assignments of federal budgetary and autonomous institutions (government assignments may not be drawn up in respect of public institutions, that is why they are excluded from the fetch), $87.65 \%$ of government assignments of institutions in the constituent entities of the Russian Federation, and $85.58 \%$ of municipal institutions' assignments (placed by such institutions). Note that a high level of data openness has been observed for a significant period of time, which is demonstrated by retrospective indicators (Fig.1) at the federal level. At the same time, the level 
of information placement by autonomous institutions is significantly lower than the corresponding indicator for budgetary institutions, however, the bottom line is consistently over $90 \%$.

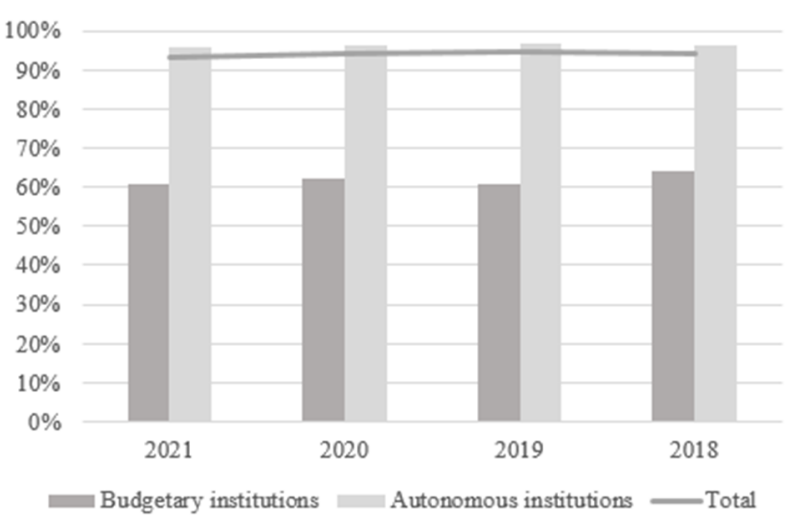

Figure 1. Dynamics of publications of state assignments, federal level

But there are some regional differences: the majority of regions $(64 \%$, or 54 constituent entities of the Russian Federation including St. Petersburg, the Orenburg Region, the Perm Territory, etc.) are characterized by a high transparency level for information on government assignments (they place more than $90 \%$ of approved documents); institutions from $29 \%$ of regions (25 constituent entities of the Russian Federation including the Arkhangelsk Region, the Irkutsk Region, Moscow, the Nizhny Novgorod Region, etc.) place data on assignments for services (works) partially-they publish 60-90\% of documents; less than $10 \%$ of regions (the Kurgan Region, the Republic of Tatarstan, etc.) demonstrate an insufficient transparency level (they publish less than $60 \%$ of approved documents).

It is noteworthy that the analysis of publications of state assignments of regional autonomous and budgetary institutions in retrospect (Table 1) reflects a decrease in publication activity and, as a consequence, budgetary openness. This situation may be due to some weakening of attention to the issues of openness at the regional level, insufficient interest of the inspectors and the expert community to the Official website for information on government and municipal institutions. At the same time, this is the only open area where you can get comprehensive information about state and municipal institutions.

Table 1. Transparency level of regional government assignments

\begin{tabular}{|c|c|c|c|}
\hline \multirow{2}{*}{ Year } & \multicolumn{3}{|c|}{ Share of published documents } \\
\hline & $>90 \%$ & $60-90 \%$ & $<60 \%$ \\
\hline 2021 & 54 regions & 25 regions & 6 regions \\
\hline 2020 & 65 regions & 20 regions & - \\
\hline 2019 & 67 regions & 18 regions & - \\
\hline 2018 & 72 regions & 13 regions & - \\
\hline 2017 & 71 regions & 14 regions & 1 region \\
\hline
\end{tabular}

Overall, data on government (municipal) assignments can be characterized as objects with a high transparency level: they established legal principles and rules of placement, implemented special-purpose platforms for publication within which the information on services (works) is provided in available and clear form.

The Official website for information on government and municipal institutions, based on an internal methodology, maintains its own rating of information transparency of institutions in the context of the constituent entities of the Russian Federation. The city of Sevastopol has the highest rating at the moment in 2021. Another 10 regions (Lipetsk region, Penza region, etc.) receive estimates from 0.8 to 0.9 (maximum value 1). The value is lower than 0.4 in 7 regions (Novosibirsk region, St. Petersburg, etc.). It should be noted that this rating characterizes the information openness of institutions as a whole, taking into account the placement of data on a number of parameters, including the publication of government assignments, financial statements, information about property, etc.

At the same time, the norms of the Government Decree of $06 / 26 / 2015$ for federal executive bodies engaged in the development of policy in the established area of activity (they maintain the above-mentioned all-Russian lists, determine the principles of financing the industry), the obligation is established to publish information on the Single Portal for the Budget System of the Russian Federation (until 2020 - on the Official website for information on government and municipal institutions) on the values of the basic cost standards and industry coefficients to the basic cost standards, which form the basis for the formation of the volume of financial support for public institutions. It should be noted that the section for presenting the relevant data provides the possibility of placing any documents of a budgetary nature and has a low level of functional openness: the published documents are not subject to systematization and are partially identifiable before they are opened. In addition, information on the values of the basic cost standards and industry coefficients to the basic cost standards at the federal level was published in relation to $63 \%$ (17 out of 27 ) spheres of activity, and the assessment of the relevance of documents and the degree of their applicability in the current budget cycle seems to be limited due to the virtual lack of appropriate identifiers.

Also, in accordance with the Procedure for maintaining the register of agreements (contracts) on the provision of subsidies, budget investments, interbudgetary transfers (order of the Ministry of Finance of the Russian Federation dated July 30, 2020 No. 153n), the corresponding register of subsidies, including data on subsidies for financial support for the implementation of state assignment, are subject to publication on the Single Portal for the Budget System of the Russian Federation. For several months, this section of the system (including posted open data) has been unavailable. In addition, amendments to the Procedure have been prepared that significantly reduce 
the list of published information: information about recipients, the intended purpose of the subsidy, targets for the results of its use, the transfer schedule and other information will no longer be public. Thus, according to a number of parameters, at the federal level, it is advisable to increase the level of budgetary openness of public services, which is due to the formal nature of posting information on standard costs and subsidies for financial support of the state assignment.

Regional procedures for the formation of a state assignment for the provision of public services (performance of work) and financial support of the state assignment, as a rule, determine the need to publish information on the standard costs of the provision of public services (basic cost standards, sectoral adjusting coefficients). At the same time, in 36 constituent entities of the Russian Federation (Arkhangelsk Oblast, Vologda Oblast, Altai Republic, Moscow Oblast, etc.), such a duty is not fixed (Fig. 2), which means there is an actual lack of open information about public finance in terms of services.

The most common ways of publishing the values of basic cost standards specified in regional orders are publication on the Official website for information on government and municipal institutions (20 constituent entities of the Russian Federation: Lipetsk Region, Pskov Region etc.) or posting on the official resources of the executive authorities of constituent entities of the Russian Federation (24 constituent entities of the Russian Federation: Perm Territory, Tver Region, Sevastopol, etc.).

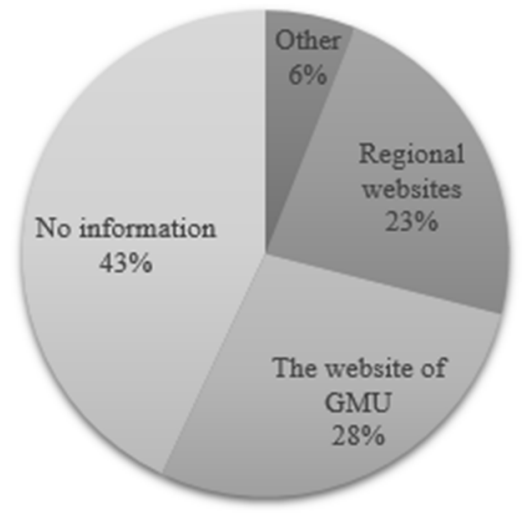

Figure 2. Baseline publication information

It should be noted that in accordance with the Order of the Ministry of Finance of the Russian Federation of July 21, 2011 No. 86n "On approval of the procedure for providing information by a state (municipal) institution, posting it on the official website on the Internet and maintaining the specified site", information on standard costs is not included in list of data published on the site. And according to the technical documentation, the platform does not provide the corresponding functionality. Thus, the implementation of the norm on the publication of standards on the Official website for information on government and municipal institutions, enshrined in the procedures, is not possible and is formal in nature; this information remains unavailable for public consideration. We note that in a number of cases (for example, in the order of the Krasnodar Territory), the wording of the norm on the publication of standards for the cost of providing services provides for such publication only if there is an appropriate technical capability on the official website for information on government and municipal institutions.

At the same time, the content analysis of the official resources of the authorities showed that the obligation to publish the standards for the provision of services on the official websites of regional authorities in most cases $(92 \%, 22$ constituent entities of the Russian Federation) is observed, but often the relevant information, as in the case with federal regulations, is not systematized, the ability to search and identify the validity period of documents is limited, which makes it difficult to analyze them by interested parties.

Other options for publishing standards, provided for by regional orders ( 5 constituent entities of the Russian Federation), combine the provisions on the placement of documents on the Single Portal for the Budget System of the Russian Federation (such functionality is provided) and wording that does not allow one to unambiguously determine the publication procedure and the corresponding resource (for example, "in the prescribed manner on the official website" - Vladimir region, "on the official website" - Tambov region) [11].

Analysis of documents and official information resources makes it possible to group the categories of information according to the level of openness (Table 1). A high level of budgetary openness is possessed by data on all Russian, federal and regional lists of services, as well as state assignments for the provision of public services (Table 2). Partially open one is information about the standards for the provision of public services (not published by all subjects of data provision, low level of functional accessibility) and a subsidy for financial support for the fulfillment of a state task at the federal level. However, there is no public information on subsidies at the regional level and is not available for public review [12].

Table 2. Level of budgetary openness

\begin{tabular}{|l|l|l|}
\hline $\begin{array}{c}\text { Categories of } \\
\text { information }\end{array}$ & Federal level & Regional level \\
\hline Lists of services & $\begin{array}{l}\text { High level of } \\
\text { openness }\end{array}$ & $\begin{array}{l}\text { High level of } \\
\text { openness }\end{array}$ \\
\hline $\begin{array}{l}\text { Government } \\
\text { assignments }\end{array}$ & $\begin{array}{l}\text { High level of } \\
\text { openness }\end{array}$ & $\begin{array}{l}\text { High level of } \\
\text { openness }\end{array}$ \\
\hline $\begin{array}{l}\text { Service cost } \\
\text { rates }\end{array}$ & $\begin{array}{l}\text { Partial } \\
\text { openness }\end{array}$ & Partial openness \\
\hline Subsidies & $\begin{array}{l}\text { Partial } \\
\text { openness }\end{array}$ & $\begin{array}{l}\text { No open } \\
\text { information } \\
\text { available }\end{array}$ \\
\hline
\end{tabular}

Thus, it is advisable to take actions to increase the level of openness of information on the financial support of public services at both the federal and regional levels, including ensuring the timely publication of relevant documents in machine-readable 
form and the functional availability of information resources.

\section{Conclusion}

Under the conditions of increasing relevance of issues on increasing the transparency level of government institutions, it is necessary and reasonable to extend the scope of open information on public finance because such information directly demonstrates the target nature and areas of the government budget disbursement.

We should note that the transparency of financial information in the Russian Federation is at an extremely high level in comparison with other areas. For example, it is easier and faster to make a retrospective list of contracts concluded by an educational institution than to find statistical information on mean grades for final examinations of its graduates. The positions in international ratings also confirm this statement.

At the same time, we think we should focus on the transparency of information interesting not only for subject specialists and experts but also for a wider set of people. Such data may include information on providing and financing government (municipal) services as an activity which can be seen and evaluated by citizens in their daily life. The exercise of the right for free public access to the detailed information on the structure of budget expenses enables people to participate in social life, increase community commitment and confidence in government and municipal authorities.

\section{References}

1. Official site of The Federal Service for Supervision of Communications, Information Technology, and Mass Media, The digital threat pyramid Retrieved from: https://rkn.gov.ru/news/rsoc/news73380.htm

2. Data is the new gold, Retrieved from: https://www2.deloitte.com/global/en/pages/realestate/articles/future-real-estate-data-newgold.html

3. OECD Policy Brief 2005 Retrieved from: http://www.oecd.org/dataoecd/1/35/34455306.p df

4. V.V. Klimanov, A.A. Michailova, Finance, 7 (2014)

5. Open Budget Servey Retrieved from: https://www.internationalbudget.org/openbudget-survey/open-budget-survey-2019-0

6. V.V. Klimanov, A.A. Mikhailova, Working Papers 041922, (2019).

7. Openness of the state in Russia Retrieved from: https://cpur.ru/research_pdf/open-gov-2019.pdf

8. N.A.Guz, Economy. Taxes. Right, 6 (2016)

9. N.V. Golovanova, Financial journal, 3 (2015).

10. S.E. Gasumova, Sociology of authority, 6 (2011).
11. O.V. Butorina, N.P. Pazdnikova, Y.V. Karpovich, Espacios, 39(27) (2018).

12. Z. Mingaleva, N. Pazdnikova, E.A. Mitrofanova, Asian Social Science, 10 (2014). 